Tropical Journal of Pharmaceutical Research December 2016; 15 (12): 2701-2708

ISSN: $1596-5996$ (print); 1596-9827 (electronic)

(C) Pharmacotherapy Group, Faculty of Pharmacy, University of Benin, Benin City, 300001 Nigeria.

All rights reserved.

Available online at http://www.tjpr.org

Original Research Article

http://dx.doi.org/10.4314/tjpr.v15i12.23

\title{
Synthesis of allitol from D-psicose using ribitol dehydrogenase and formate dehydrogenase
}

\author{
Hinawi AM Hassanin, Rebaone Letsididi, Marwa YF Koko, Wanmeng Mu, \\ Ammar Elferga and Bo Jiang* \\ State Key Laboratory of Food Science and Technology, School of Food Science and Technology, Jiangnan University. 1800
} Lihu Avenue, Wuxi 214122, China

${ }^{*}$ For correspondence: Email: bjiang@jiangnan.edu.cn; Tel: +86-510-85329055; Fax: +86-510-85919625

Received: 21 July 2016

Revised accepted: 10 November 2016

\begin{abstract}
Purpose: To synthesize allitol from D-psicose by a combination of novel ribitol dehydrogenase (RDH) and formate dehydrogenase (FDH) under optimised production conditions.

Methods: RDH and FDH genes were cloned and introduced into $p E T-22 b(+)$ vectors for expression in Escherichia coli to produce the corresponding enzymes. The effects of temperature, $\mathrm{pH}$, shaking velocity $(75,100,125$, and $150 \mathrm{rpm})$, and shaking type (horizontal and vortex) were optimised to maximise the production yield of allitol. The final product was purified and subjected to nuclear magnetic resonance (NMR) spectroscopy, infrared (IR) spectrometry, and liquid chromatography-mass spectrometry (LC-MS) to confirm its structure.

Results: The optimal $\mathrm{pH}$ and temperature for the reaction were 7.5 and $40^{\circ} \mathrm{C}$, respectively. The results revealed that allitol yield significantly increased with increase in reaction shaking velocity and reached a maximum yield of $95.60 \pm 0.54 \%$ at $150 \mathrm{rpm}$ shaking velocity after $6 \mathrm{~h}$ of reaction. When the reaction was run under horizontal shaking, allitol yield increased from $100.00 \pm 6.05$ (without shaking) to 124.20 $\pm 9.70 \%$. Twenty milligrams of D-psicose were successfully reduced to allitol under optimum conditions with a high production yield of $16.7 \pm 0.62 \mathrm{mg}$ after $6 \mathrm{~h}$. No by-products were formed during or after the reaction. The produced allitol had a purity of $95 \%$, and its structure was confirmed by HPLC, IR, LCMS, and NMR spectral analyses.

Conclusion: Using D-psicose as a substrate, allitol with $95 \%$ purity was successfully produced by the combination of novel RDH and FDH.
\end{abstract}

Keywords: Allitol, Ribitol dehydrogenase, Formate dehydrogenase, D-Psicose, Providencia alcalifaciens

Tropical Journal of Pharmaceutical Research is indexed by Science Citation Index (SciSearch), Scopus, International Pharmaceutical Abstract, Chemical Abstracts, Embase, Index Copernicus, EBSCO, African Index Medicus, JournalSeek, Journal Citation Reports/Science Edition, Directory of Open Access Journals (DOAJ), African Journal Online, Bioline International, Open-J-Gate and Pharmacy Abstracts

\section{INTRODUCTION}

Rare sugars are monosaccharides that are less abundant in nature than common sugars such as D-fructose and D-glucose. Their rarity limits their large-scale extraction and separation from natural sources. These compounds, which are classified as 'sugars' and 'sugar alcohols,' have interesting characteristics, and are used in both food production and pharmaceuticals [1-6]. The use of inexpensive raw substrates for the production of rare sugars is now attracting considerable attention. Previous studies confirmed the validity of this approach; for example, L-xylulose, D-tagatose, D-sorbose, Dpsicose, D-talitol, and allitol were successfully produced using microorganisms [7-11]. Among these, allitol is a rare hexitol that is synthesised 
by the reduction of D-psicose [12]. In the natural world, allitol is present in plants of the Itea genus (Itea virginica L.) and certain fungi [13,14]. Izumori [10] reported a useful strategy for processing most hexoses, called the Izumoring map, in which allitol and galactitol are placed at symmetric points of $D$ and $L$ in the production zone of hexose sugars.

The use of microorganisms to produce rare sugars has various advantages, such as the use of inexpensive catalysts that do not require purification and in the avoidance of cofactor recycling in vitro, as enzymatic conversion is more controllable and scalable. The use of both bacterial reduction (using Enterobacter strain 221) and enzymatic reaction (using ribitol dehydrogenase: $\mathrm{RDH}$ ) to produce allitol from $\mathrm{D}$ psicose has been reported $[12,15,16]$. In recent studies, a new RDH from Providencia alcalifaciens RIMD 1656011 and formate dehydrogenase (FDH) from the methanolassimilating yeast Ogataea parapolymorpha DL1 were cloned and characterised $[17,18]$. The new RDH was found to possess high specificity towards ribitol and allitol and low specificity towards other polyols (D-sorbitol, L-arabitol, galactitol, D-mannitol, inositol, and glycerol) regarding catalytic targeting [17].

In the current paper, we report for the first time the use of new RDH from $P$. alcalifaciens RIMD 1656011 and FDH from the methanolassimilating yeast $O$. parapolymorpha DL-1 for the production of allitol. Allitol was completely separated, and its structure was characterised using infrared (IR), liquid chromatography-mass spectrometry (LC-MS), and nuclear magnetic resonance (NMR) spectral data. We also investigated the effects of shaking velocity and shaking type to standardise the reaction time for maximising allitol yield.

\section{EXPERIMENTAL}

\section{Chemicals and plasmids}

An allitol standard was purchased from SigmaAldrich (Shanghai, China). D-psicose was previously prepared in our laboratory from Dfructose [19]. Two reconstructed plasmids, containing FDH from the methanol-assimilating yeast $O$. parapolymorpha $\mathrm{DL}-1$ and $\mathrm{RDH}$ from $P$. alcalifaciens RIMD 1656011 were synthesised by Sangon Biological Engineering Technology and Services (Shanghai, China), in accordance with the protocol reported by Hassanin et al [17].

\section{Expression and separation of crude RDH and FDH from E. coli BL21}

A gene (gene locus_tag: HPODL_3660) with the protein ID EFW95288.1 and a target gene (gene locus_tag: HMPREF1565_2774) with the protein ID number EUD03977.1 have been identified as hypothetical sequences encoding FDH and $\mathrm{RDH}$, respectively. The genes $\mathrm{RDH}$ and $\mathrm{FDH}$ were cloned and introduced into the pET-22b(+) vector using Ndel and Xhol sites and an in-frame fusion His6-tag sequence at the C-terminus in the reconstructed plasmids. The plasmids, pET-Pral$\mathrm{RDH}$ and $\mathrm{pET}-\mathrm{Op}-\mathrm{FDH}$, were transformed into $E$. coli BL21 for RDH and FDH overexpression. $E$. coli BL21 cells harbouring the plasmids were grown separately in $500-\mathrm{mL}$ flasks containing $250 \mathrm{~mL}$ of Luria-Bertani medium supplemented with ampicillin $(100 \mu \mathrm{g} / \mathrm{mL})$ and incubated at 37 ${ }^{\circ} \mathrm{C}$. When the culture had attained an optical density of 0.6 at $600 \mathrm{~nm}$, isopropyl $\beta-\mathrm{D}-1$ thiogalactopyranoside (IPTG) was added to the culture to a final concentration of $1 \mathrm{mM}$, and then the expression of $\mathrm{RDH}$ and $\mathrm{FDH}$ was induced at $30{ }^{\circ} \mathrm{C}$ for $5 \mathrm{~h}$.

Subsequently, the cells were collected by centrifugation $(8,000 \mathrm{rpm}$; $10 \mathrm{~min})$, rinsed with lysis buffer (50 mM Tris buffer, $100 \mathrm{mM} \mathrm{NaCl}, \mathrm{pH}$ 7.5), resuspended in lysis buffer, and disrupted by ultra-sonication at $4{ }^{\circ} \mathrm{C}$ using a Vibra-Cell TM 72405 Sonicator (BioBlock Scientific, Illkirch, France). The supernatants obtained after centrifugation (10,000 rpm; $30 \mathrm{~min})$ was used as the crude enzymes. The activities of RDH and FDH were 4.0 and 3.4 units $/ \mathrm{mL}$, respectively.

\section{RDH and FDH assays}

The protein concentration was measured following the standard Bradford method. Enzyme activities were assayed by measuring $\mathrm{NADH}$ absorbance at $340 \mathrm{~nm}$. Furthermore, for the $\mathrm{RDH}$ assay, a reaction mixture consisting of $1 \mathrm{~mL}$ each of the following was used: $50 \mathrm{mM}$ glycine$\mathrm{NaOH}$ buffer ( $\mathrm{pH}$ 10.0), $0.6 \mathrm{mM} \mathrm{NAD}^{+}, 50 \mathrm{mM}$ ribitol, and enzyme solution; absorbance was measured at $340 \mathrm{~nm}$.

For the FDH assay, the reaction mixture consisted of $1 \mathrm{~mL}$ each of the following reactants: $50 \mathrm{mM}$ phosphate buffer ( $\mathrm{pH} 6.5), 1.6$ $\mathrm{mM} \mathrm{NAD}^{+}, 160 \mathrm{mM}$ sodium formate, and enzyme solution; absorbance was again measured at 340 $\mathrm{nm}$. The reaction was started by adding the substrates. One unit of enzyme activity was defined as the amount of enzyme able to catalyse the conversion of $1 \mu \mathrm{mol} \mathrm{NAD}^{+}$to $\mathrm{NADH}$ per minute at $30^{\circ} \mathrm{C}$. 


\section{Optimisation of temperature and $\mathrm{pH}$ for allitol production}

A reaction mixture of $1 \mathrm{~mL}$ was used $(10 \mathrm{mg}$ of D-psicose, $10 \mathrm{mg}$ of sodium formate, $2 \mathrm{mM}$ $\mathrm{NAD}^{+}$, and 0.5 units of RDH and $\left.\mathrm{FDH}\right)$. Three buffer systems, i.e. phosphate buffer $(50 \mathrm{mM}, \mathrm{pH}$ 5.0 - 7.0), Tris- $\mathrm{HCl}(50 \mathrm{mM}, \mathrm{pH} 7.5-9.0)$, and glycine $-\mathrm{NaOH}(50 \mathrm{mM}$, pH $9.5-11.0)$, were used to determine the optimal $\mathrm{pH}$ for the two enzymes in the reduction of D-psicose to allitol. The optimal temperature for $\mathrm{RDH}$ and $\mathrm{FDH}$ activities in the reaction was measured by assaying the coupled enzymes reaction over the temperature range of $25-60{ }^{\circ} \mathrm{C}$ at intervals of 5 ${ }^{\circ} \mathrm{C}$.

\section{Optimisation of shaking velocity and shaking type for allitol production}

To investigate the effects of shaking velocity and shaking type on allitol production, the enzymatic reaction was carried out as follows. A reaction mixture containing $1 \%$ D-psicose, $1 \%$ $\mathrm{HCOONa}, 2 \mathrm{mM} \mathrm{NAD}{ }^{+}$, and 1.0 unit each of $\mathrm{RDH}$ and $\mathrm{FDH}$ in $2.0 \mathrm{~mL}$ of $50 \mathrm{mM}$ Tris- $\mathrm{HCl}$ buffer $(\mathrm{pH} 7.5)$ was introduced into test tubes. This mixture was shaken using four different shaking velocities $(75,100,125$, and $150 \mathrm{rpm})$ and two shaking types (horizontal and vortex) in a water bath shaker.

\section{Allitol production}

The reduction of D-psicose to allitol by the coupled RDH and FDH reaction was carried out as follows using the above-mentioned conditions. The reaction mixture consisted of $1 \% \mathrm{D}$-psicose, $1 \% \mathrm{HCOONa}, 2 \mathrm{mM} \mathrm{NAD}^{+}$, and 1.0 unit each of $\mathrm{RDH}$ and $\mathrm{FDH}$ in $2.0 \mathrm{~mL}$ of $50 \mathrm{mM}$ Tris- $\mathrm{HCl}$ buffer ( $\mathrm{pH}$ 7.5). The mixture was shaken at 150 rpm (horizontal shaking) and $40^{\circ} \mathrm{C}$ for $6,24,48$, and $72 \mathrm{~h}$. The rate of allitol production was measured by high-performance liquid chromatography (HPLC) (1200 Series; Agilent Technologies, Santa Clara, CA, USA).

\section{HPLC}

For the HPLC analysis, samples were heated at $95^{\circ} \mathrm{C}$ for $5 \mathrm{~min}$ to inactivate enzymes, and then centrifuged at $10,000 \mathrm{rpm}$ for $10 \mathrm{~min}$ at ambient temperature. The supernatants obtained after centrifugation were then passed through a 0.45 $\mu \mathrm{m}$ filter and analysed by HPLC coupled with an IR detector (Shodex RI-101) and SUGAR-PAK column $(6.5 \times 300 \mathrm{~mm})$ at a column temperature of $85^{\circ} \mathrm{C}$. Water was used as the mobile phase at a flow rate of $0.4 \mathrm{~mL} / \mathrm{min}$.

\section{Allitol purification}

Allitol purification was achieved by HPLC. It was separated on a SUGAR-PAK column $(6.5 \times 300$ $\mathrm{mm}$ ) with water as mobile phase at the flow rate of $0.4 \mathrm{~mL} / \mathrm{min}$ at $85^{\circ} \mathrm{C}$. The collected eluate of pure allitol was placed in a freeze-dryer (Labconco Corporation, Kansas City, USA). To measure the purity of the purified allitol (freezedried), $2 \mathrm{mg}$ of allitol powder was dissolved in 1 $\mathrm{mL}$ of distilled water and detected by HPLC.

\section{NMR and IR spectroscopy}

A total of $10 \mathrm{mg}$ of freeze-dried allitol (purity 95 $\%$ ) was dissolved in D2O (NMR solvent) at 25 ${ }^{\circ} \mathrm{C}$. Then, the sample was loaded into a Bruker Avance III Digital NMR Spectrometer (Bruker, Karlsruhe, Germany) for 13C NMR spectroscopy. The spectra were processed with Bruker Topspin 2.1 software (Bruker). The IR spectra were processed using a Thermo/Nicolet Nexus 470 FT-infrared spectrometer.

\section{LC-MS}

LC-MS (Waters Acquity UPLC and Waters Maldi Synapt Q-T of MS) was performed in negativeion detection mode. Ultra-pure synthetic air was used as the desolvation gas (flow rate, $700 \mathrm{~L} / \mathrm{h}$ ), and MS fragment ions were obtained with collision energy of $6 \mathrm{eV}$. The mobile phase consisted of $80 \%$ acetonitrile and $0.1 \%$ ammonia, and the run time was $15 \mathrm{~min}$, with a flow rate of $0.3 \mathrm{ml} / \mathrm{min}$ and injection volume of 1 $\mu \mathrm{L}$.

\section{Statistical analysis}

All experiments were performed in triplicate for each sample. The data are presented as mean \pm standard deviation. The experimental data were analysed by one-way analysis of variance using SPSS 17.0 software (SPSS, Inc., Chicago, IL, USA). Comparison of group means was accomplished using Duncan's multiple range tests. Unless noted otherwise, $p<0.05$ was considered to indicate a significant difference.

\section{RESULTS}

\section{Optimum $\mathrm{pH}$ and temperature}

To determine the optimal $\mathrm{pH}$ and temperature, the reaction mixture was incubated for $6 \mathrm{~h}$. Figure $1 \mathrm{~A}$ shows that the optimal $\mathrm{pH}$ for allitol production was 7.5 , whereas at $\mathrm{pH} 5.0,5.5,6.0$, $6.5,7.0,8.0,9.0,10.0$, and 11.0 , the relative yield were $34.2 \pm 3.9,69 \pm 4.3,86.0 \pm 4.5,97.0 \pm$ 
$5.2,98.0 \pm 4.1,71.4 \pm 5.5,59.3 \pm 5.7,37.7 \pm 6.5$, and $29 \pm 4.2 \%$, respectively.

As shown in Figure 1B, the reaction was also carried out within the temperature range of 25 $60{ }^{\circ} \mathrm{C}$. In the reaction mixture, maximum allitol production was achieved at a temperature of 40 ${ }^{\circ} \mathrm{C}$. The production of allitol significantly increased from $68 \pm 2.1 \%$ at $25{ }^{\circ} \mathrm{C}$ and then decreased above $40{ }^{\circ} \mathrm{C}$ to $91.0 \pm 3.2 \%$ at $45^{\circ} \mathrm{C}$, reaching $0 \%$ at $60{ }^{\circ} \mathrm{C}$.
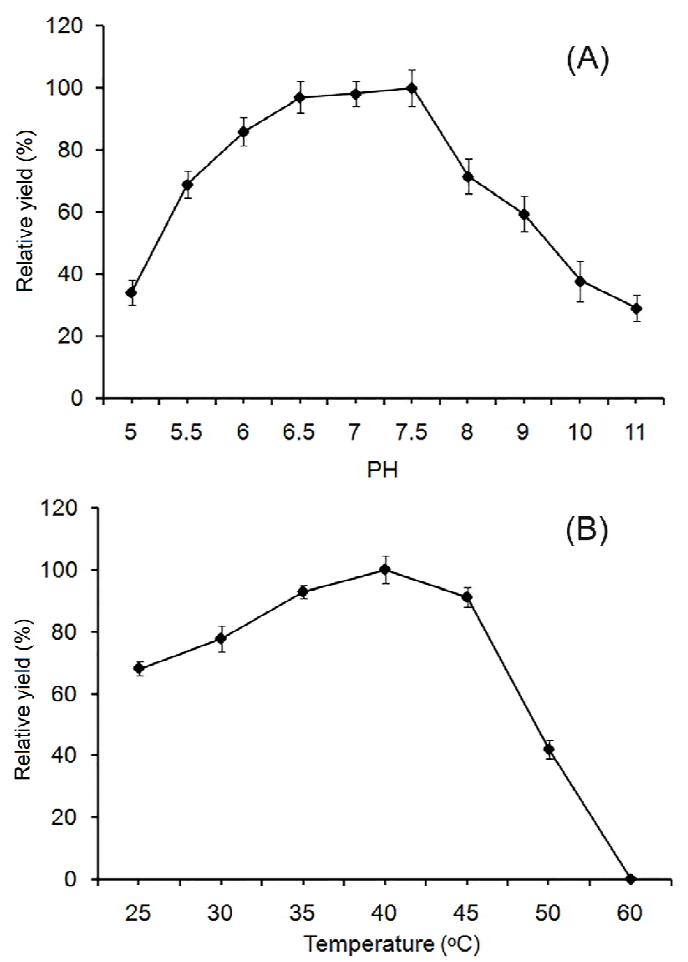

Figure 1: (A) Effect of $\mathrm{pH}$ on the reaction system. Values are the means of three replicates \pm standard deviation. (B) Effect of temperature on the reaction system. Values are the means of three replicates \pm standard deviation.

\section{Effect of shaking velocity and shaking type}

The effects of shaking velocity and shaking type on allitol production by the two enzymes $(\mathrm{RDH}$ and FDH) were also investigated in this study. Allitol production was investigated with two types of shaking (horizontal and vortex). The production yield of allitol increased by $24.2 \pm 9 \%$ and $13.7 \pm 5 \%$ for horizontal and vortex shaking, respectively, compared with that in the control (without shaking).

In addition, allitol production was tested with four different shaking velocities $(75,100,125$, and $150 \mathrm{rpm}$ ) for up to $24 \mathrm{~h}$ at $40{ }^{\circ} \mathrm{C}$ and $\mathrm{pH}$ 7.5. As shown in Figure 2, allitol production was significantly increased at $150 \mathrm{rpm}$, with the production yield reaching $94 \pm 0.73 \%$ after just 6 h. Shaking velocities of $0,75,100$, and $125 \mathrm{rpm}$ for $6 \mathrm{~h}$ resulted in production yields of $69.79 \pm$ 8.6, $64.0 \pm 3.5,59.52 \pm 2.7$ and $77.4 \pm 2.4 \%$, respectively.

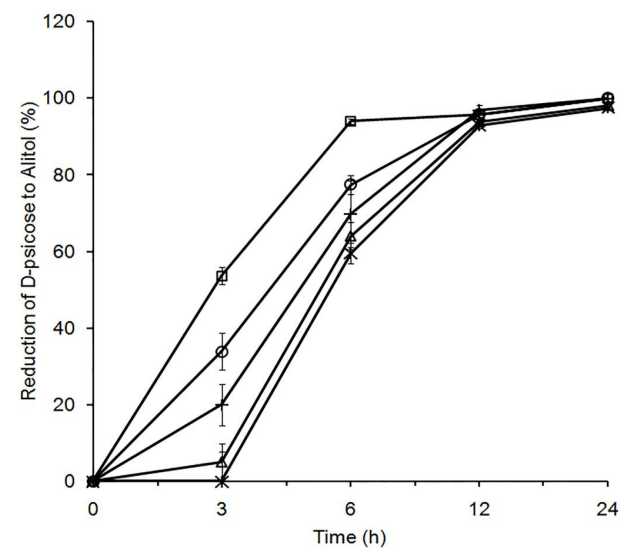

Figure 2: Effect of shaking velocity on allitol production. The shaking velocity was tested by measuring the reduction of D-psicose at () $150 \mathrm{rpm}$, (०) $125 \mathrm{rpm},\left(_{*}\right) 100 \mathrm{rpm},(\Delta) 75 \mathrm{rpm}$ and (+) $0 \mathrm{rpm}$. Values are mean of three replicates \pm standard deviation

\section{Reduction of D-psicose to allitol under optimal conditions}

The reduction of $\mathrm{D}$-psicose to allitol was then conducted under optimal conditions $\left(40^{\circ} \mathrm{C}\right.$, Tris$\mathrm{HCl} \mathrm{pH} \mathrm{7.5,} 150 \mathrm{rpm}$, and horizontal shaking) using one unit of $\mathrm{RDH}$ and one unit of $\mathrm{FDH}$. The reaction revealed a reduction of D-psicose to allitol with production yields of $16.75 \pm 0.62$, $17.86 \pm 0.6,18.3 \pm 0.8,18.85 \pm 0.6$, and $18.93 \pm$ $0.82 \mathrm{mg} \mathrm{mL}^{-1}$ at $6,12,24,48$, and $72 \mathrm{~h}$, respectively, without any by-product formation (Figure 3).

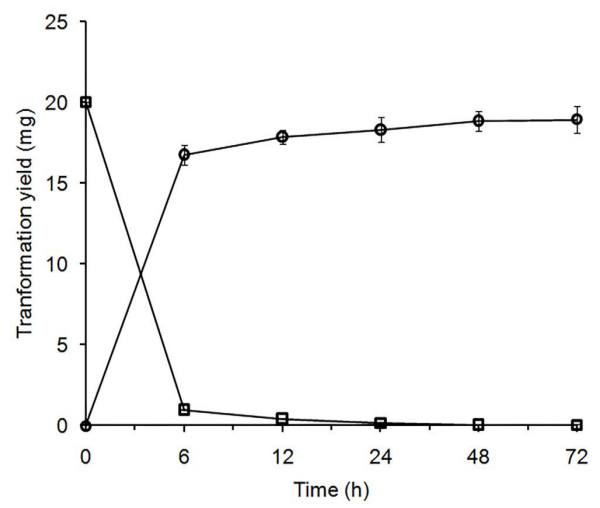

Figure 3: Reduction of D-psicose to allitol by ribitol dehydrogenase and formate dehydrogenase. ( $\square$ ) Dpsicose; (O) allitol. The initial concentration of Dpsicose was $1 \%$. The production of allitol and decrease in D-psicose are presented as the transformation yield $(\mathrm{mg})$. Values are means of three replicates \pm standard deviation

Trop J Pharm Res, December 2016; 15(12): 2704 


\section{Product structure identification}

The reaction mixture was analysed by HPLC; the retention times of the produced allitol and the authentic allitol standard were identical (Figure 4A). The purity of the purified allitol was approximately $95 \%$. The ${ }^{13} \mathrm{C}$ NMR (Peak no. 1: 63.20, Peak no. 2: 73.01 and Peak no. 3: 73.17) and IR data (Figure 4B) analyses confirmed that the product was allitol. The product was also analysed by LC-MS; as shown in Figure 5 , the measured mass from the spectrum was 182.1, which is identical to the molar mass of allitol.

\section{DISCUSSION}

In this study, two novel enzymes, RDH and FDH from Providencia alcalifaciens RIMD 1656011 and the methanol-assimilating yeast Ogataea parapolymorpha DL-1, respectively, were used for the production of allitol from D-psicose. Only a few studies have reported the use of RDH for producing allitol from D-psicose, such as isolation of RDHs from Klebsiella pneumonia IFO $3321[16]$.
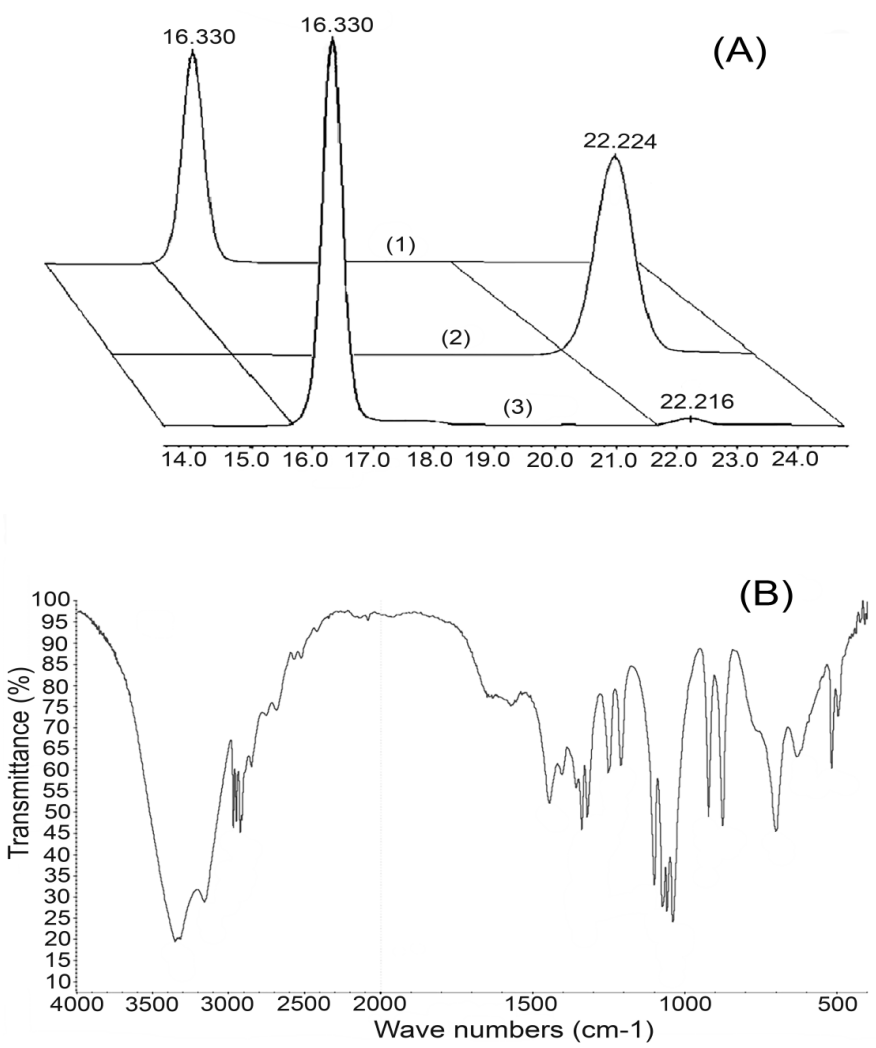

Figure 4: (A) High-performance liquid chromatography analysis of the reduction of D-psicose to allitol by ribitol dehydrogenase (RDH) and formate dehydrogenase (FDH). (1) Authentic allitol, (2) Authentic D-psicose, and (3) Reaction system. (B) Infrared spectrum of allitol produced by RDH from Providencia alcalifaciens RIMD 1656011

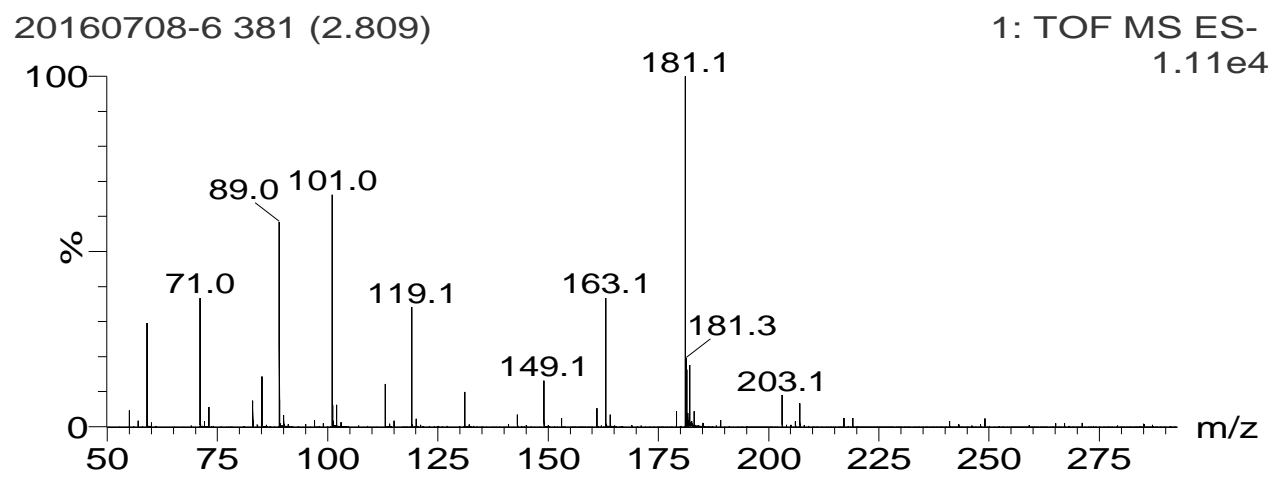

Figure 5: The mass spectrum of purified allitol produced from D-psicose 
In addition, a recent study by Zhu et al [20] achieved the co-expression of multiple enzymes in $E$. coli using whole cells for allitol production. $\mathrm{RDH}$ enzymes have been isolated from many microorganisms, such as RDH from $E$. agglomerans strain 221e, Rhodobacter sphaeroides, Gluconobacter oxydans and Zymomonas mobilis [16,21-23]. However, only RDH from K. pneumonia IFO 3321 was coupled with FDH and optimised for allitol production [16]. Allitol can also be produced directly from Dfructose through three enzymes: D-tagatose-3epimerase (DTEase), RDH, and FDH. The important consideration when producing allitol directly from D-fructose is that RDH should be active on allitol and not active on D-sorbitol or Dmannitol. If polyol dehydrogenase is active on these substrates, D-fructose could be reduced to D-sorbitol or D-mannitol, which would result in impurities in the final product [16]. However, the $\mathrm{RDH}$ from $P$. alcalifaciens that we investigated was not active on D-sorbitol and D-mannitol, which indicated that the enzyme can be used for the production of allitol directly from D-fructose [17]. To the best of our knowledge, there is also an $\mathrm{RDH}$ from $K$. pneumonia which is not active on D-sorbitol and D-mannitol [16].

RDH from $P$. alcalifaciens achieved a high yield of allitol across a wide $\mathrm{pH}$ range, which is extremely interesting for industrial uses. The optimal $\mathrm{pH}$ for the reaction mixture with $\mathrm{RDH}$ from $K$. pneumoniae IF0 $3321 \mathrm{~K}$ was previously found to be 8.0 [16]. This shows that there is no significant difference between the optimal $\mathrm{pH}$ in this study and those in other reported studies on allitol production.

It was also revealed that temperature had a great effect on the use of RDH from $P$. alcalifaciens for allitol production. However, such variations in temperature were due to different optimal temperatures of RDH and FDH. Takeshita et al [16] reported that they produced allitol at a temperature of $30{ }^{\circ} \mathrm{C}$. The previously reported optimal temperatures for $\mathrm{RDH}$ for producing allitol are in agreement with that for $\mathrm{RDH}$ from $P$. alcalifaciens, which exhibited high activity for allitol production within the range of $30-40^{\circ} \mathrm{C}$.

In addition, there was no significant difference in the level of allitol production between horizontal and vortex shaking. From the results of horizontal shaking, this was observed to be similarly effective for allitol production for both $\mathrm{RDH}$ and $\mathrm{FDH}$, increasing the production yield of allitol.

There was no significant difference among the shaking velocities of 0,75 , and $100 \mathrm{rpm}$.
However, shaking at $125 \mathrm{rpm}$ resulted in a significantly higher yield $(p<0.05)$ compared with 75 and $100 \mathrm{rpm}$. Shaking at $150 \mathrm{rpm}$ also resulted in a significantly higher yield $(p<0.05)$ compared with all other tested shaking velocities $(0.0,75,100$, and 125). This showed that the allitol production yield was increased by shaking velocities above $100 \mathrm{rpm}$. A further increase of shaking velocity to $150 \mathrm{rpm}$ reduced the time until the end of the reaction was reached and accelerated the production of allitol from Dpsicose. No previous studies examined the effects of shaking velocity and shaking type on allitol production.

In the next stage of the study, allitol was produced under the previously determined optimal conditions, and the reaction was characterised using HPLC after heating the reaction mixture at $95^{\circ} \mathrm{C}$ for $5 \mathrm{~min}$ to inactivate the enzymes. The production yield reached approximately $17.86 \pm 0.6 \mathrm{mg}$ in just $12 \mathrm{~h}$ from $20 \mathrm{mg}$ of D-psicose. Similarly, Takeshita et al [16] reported that almost all D-psicose was transformed into allitol after $48 \mathrm{~h}$. Our enzyme system gave a high reduction yield of approximately $83 \%$ within a short period of $6 \mathrm{~h}$. The obtained product was then subjected by NMR, IR, and LC-MS analyses to confirm that it was allitol.

A comparison of the ${ }^{13} \mathrm{C}$ NMR results for allitol produced by RDH from K. pneumoniae IFO3321 (Peak no. 1: 63.20, Peak no. 2: 73.0 and Peak no. 3: 73.2), Enterobacter agglomerans strain 221e (Peak no. 1: 63.22, Peak no. 2: 73.01 and Peak no. 3: 73.18) and novel isolated strain of Klebsiella oxytoca G4A4 (Peak no. 1: 63.23, Peak no. 2: 73.02 and Peak no. 3: 73.18), revealing no differences among the ${ }^{13} \mathrm{C}$ NMR results $[16,12.24]$. IR spectrum of allitol produced by $P$. alcalifaciens is identical to the IR spectrum of allitol produced with the reaction system reported by Takeshita et al [16].

The mass spectrum obtained by LC-MS in negative-ion detection mode $(182.1 \mathrm{~g} / \mathrm{mol})$ was identical in terms of the molar mass of allitol. This high allitol production yield using RDH from $\mathrm{P}$. alcalifaciens can decrease the time required to produce allitol for commercial uses, and can thus reduce costs.

\section{CONCLUSION}

Allitol has been successfully produced by the combination of RDH/FDH and D-psicose as a substrate. Optimization of various reaction parameters results in high-yield allitol production under experimental conditions, such as shaking 
velocity and shaking type, via the reduction of Dpsicose by $\mathrm{RDH}$ and irreversible regeneration of $\mathrm{NADH}$ from NAD ${ }^{+}$by FDH. The allitol produced is pure, being successfully characterised and confirmed by HPLC, IR, and ${ }^{13} \mathrm{C}$ NMR analyses. Thus, low-cost production of allitol on a comparatively large scale using these novel enzymes can in turn extend the range of applications of allitol to pharmaceuticals and other types of food in future.

\section{DECLARATIONS}

\section{Acknowledgement}

This work was financially supported by National Natural Science Foundation of China (nos. 31371788 and 31230057) and National High Technology Research and Development Program of China (no. 2013AA102102).

\section{Conflict of Interest}

No conflict of interest associated with this work.

\section{Contribution of Authors}

The authors declare that this work was done by the authors named in this article and all liabilities pertaining to claims relating to the content of this article will be borne by them.

\section{Open Access}

This is an Open Access article that uses a funding model which does not charge readers or their institutions for access and distributed under the terms of the Creative Commons Attribution License (http://creativecommons.org/licenses/by 14.0) and the Budapest Open Access Initiative (http://www.budapestopenaccessinitiative.org/rea d), which permit unrestricted use, distribution, and reproduction in any medium, provided the original work is properly credited.

\section{REFERENCES}

1. Muniruzzaman S, Pan $Y T$, Zeng $Y$, Atkins B, Izumori K.Elbein, A.D. Inhibition of glycoprotein processing by Lfructose and L-xylulose. Glycobiol 1996; 6: 795-803.

2. Livesey G, Brown JC. D-tagatose is a bulk sweetener with zero energy determined in rats. J Nutr 1996; 126 : 1601-1609.

3. Hadipernata M, Hayakawa S, Rachmat R. The Utilization of Rare Sugars as a Functional Food. In II Asia Pacific Symposium on Postharvest Research Education and Extension: APS2012 1011 2012; pp 369-374.
4. Bautista DA, Pegg RB, Shand PJ. Effect of L-glucose and $D$-tagatose on bacterial growth in media and a cooked cured ham product. J Food Protect 2000; 63: 71-77.

5. Hossain MA, Izuishi $K$, Maeta $H$. Protective effects of $d$ allose against ischemia reperfusion injury of the rat liver. $J$ Hepato-Biliary-Pan 2003; 10: 218-225.

6. Takata MK, Yamaguchi $F$, Nakanose $K$, Watanabe $Y$, Hatano N, Tsukamoto I, Izumori K, Tokuda $M$. Neuroprotective effect of D-psicose on 6hydroxydopamine-induced apoptosis in rat pheochromocytoma (PC12) cells. J Biosci Bioeng 2005; 100: 511-516.

7. Ahmed Z. Production of natural and rare pentoses using microorganisms and their enzymes. Electron $J$ Biotechn 2001; 4: 13-14.

8. Beerens $K$, Desmet $T$, Soetaert $W$. Enzymes for the biocatalytic production of rare sugars. $J$ Ind Microbiol Biot 2012; 39: 823-834.

9. Granstrom TB, Takata G, Tokuda M, Izumori $K$. Izumoring: a novel and complete strategy for bioproduction of rare sugars. J Biosci Bioeng 2004; 97: 89-94

10. Izumori K. Izumoring: a strategy for bioproduction of all hexoses. J Biotechnol 2006; 124: 717-722.

11. Poonperm W, Takata G, Ando Y, Sahachaisaree V, Lumyong $P$, Lumyong $S$, Izumori K. Efficient conversion of allitol to D-psicose by Bacillus pallidus Y25. J Biosci Bioeng 2007; 103: 282-285.

12. Muniruzzaman S, Tokunaga H, Izumori K. Conversion of d-psicose to allitol by Enterobacter agglomerans strain 221e. J Ferment Bioeng 1995; 79: 323-327.

13. Ayers BJ, Hollinshead J, Saville AW, Nakagawa S, Adachi I, Kato A, Izumori K, Nash RJ. Iteamine, the first alkaloid isolated from Itea virginica $L$. inflorescence. Phytochem 2014; 100: 126-131.

14. Gao JM, Dong ZJ, Liu JK. A new ceramide from the basidiomycete Russula cyanoxantha. Lipids 2001; 36 : 175-181.

15. Muniruzzaman S, Kunihisa $Y$, Ichiraku K, Izumori $K$. Purification and characterization of a ribitol dehydrogenase from Enterobacter agglomerans strain 221e. J Ferment Bioeng 1995; 79: 496-498.

16. Takeshita K, Ishida Y, Takada G, Izumori K. Direct production of allitol from $D$-fructose into $D$-psicose. Biotechnol Lett 2000; 31: 857-862.

17. Hassanin AH, Wang $X$, Zhang $T$, Mu W, Jiang B. Cloning and characterization of a new ribitol dehydrogenase from Providencia alcalifaciens RIMD 1656011. J Sci Food Agr 2015; 96: 2917-2924

18. Yu S, Zhu L, Zhou C, An T, Zhang T, Jiang B, Mu W. Promising properties of a formate dehydrogenase from a methanol-assimilating yeast Ogataea parapolymorpha $D L-1$ in His-tagged form. Appl Microbiol Biot 2014; 98 : 1621-1630.

19. Zhang L, Mu W, Jiang B, Zhang T. Characterization of $D$ tagatose-3-epimerase from Rhodobacter sphaeroides that converts $D$-fructose into $D$-psicose. Biotechnol Lett 2009; 31: 857-862.

Trop J Pharm Res, December 2016; 15(12): 2707 
20. Zhu Y, Li H, Liu P, Yang J, Zhang X, Sun Y. Construction of allitol synthesis pathway by multi-enzyme coexpression in Escherichia coli and its application in allitol production. $J$ Ind Microbiol Biot 2015; 42: 661-669.

21. Kahle C, Schneider KH, Giffhorn F. Pentitol metabolism of Rhodobacter sphaeroides Si4: purification and characterization of a ribitol dehydrogenase. J Gen Microbiol 1992; 138: 1277-1281.

22. Adachi $O$, Fujii $Y$, Ano $Y$, Moonmangmee $D$, Toyama $H$, Shinagawa $E$, Theeragool G, Lotong $N$, Matsushita $K$. Membrane-bound sugar alcohol dehydrogenase in acetic acid bacteria catalyzes L-ribulose formation and
NAD-dependent ribitol dehydrogenase is independent of the oxidative fermentation. Biosci Biotech Bioch 2001; 65: $115-125$.

23. Moon HJ, Tiwari M, Jeya M, Lee JK. Cloning and characterization of a ribitol dehydrogenase from Zymomonas mobilis. Appl Microbiol Biot 2010; 87: 205 214.

24. Han W, Zhu Y, Men Y, Yang J, Liu C, Sun Y. Production of allitol from $D$-psicose by a novel isolated strain of Klebsiella oxytoca G4A4. J Basic Microb 2014; 54: 1073-1079. 